not stabilize a triple-stranded DNA structure, as this plasmid has been shown to form a triple-stranded structure consisting of one purine strand and two pyrimidine strands, with the free single-strand being the purine strand?

This error does not diminish the value of the observation ', as the finding of a heteroduplex and altered conformation of the DNA in the transcribed plasmid suggests a hypothesis for how transcripts from unrearranged heavy-chain constant-region genes could direct switch recombination.

Janet Stavnezer

Department of Molecular Genetics, and Microbiology,

University of Massachusetts Medical School,

55 Lake Avenue North, Worcester, Massachusetts 01605, USA

Reaban ANd GRIFin REPI.y - Further DNA sequence analysis of the plasmid pBS- $\alpha$ S2.3 confirms Stavnezer's observation that transcription by T7 RNA polymerase would produce a transcript containing the polypurine sequence (AGGAG) ( $2 x$, rather than the polypyrimidine transcript reported in our manuscript ${ }^{1}$. We regret this error in our data.

But the fact that the $\mathbf{T} 7$ transcript is purine-rich would not exclude it from stabilizing an intramolecular DNA triplex. Under our transcription conditions $\left(8 \mathrm{mM} \mathrm{MgCl}_{2}\right.$ and $\mathrm{pH} 8.0$ ) a purine-purine-pyrimidine intramolecular DNA triplex is likely to form. This triplex would be stabilized by basepairing with the purine-rich $\mathrm{T} 7$ transcript via its excluded pyrimidine strand. A poly $(\mathrm{dG})-\operatorname{poly}(\mathrm{dC})$ sequence has been shown to form either a poly $(\mathrm{dG})-\operatorname{poly}(\mathrm{dG})-\operatorname{poly}(\mathrm{dC})$ or a poly $(\mathrm{dC})-\operatorname{poly}(\mathrm{dG})-\operatorname{poly}(\mathrm{dC})$ triple helix in a supercoiled plasmid, depending on the presence or absence of $\mathrm{Mg}^{2+}$, respectively ${ }^{3}$. The $+\mathrm{Mg}^{2+}$ triplex forms stably in neutral or slightly basic buffers, whereas formation of the $-\mathrm{Mg}^{2+}$ triplex is enhanced by low $\mathrm{pH}$. The formation of dG-dG-dC (ref. 4), A-A-U (ref. 5) and 5'-TGGGGAGGGGTGGGGAGGGGTGGGGAAGG-3' purine-purine-pyrimidine (ref. 6) colinear triplexes under similar buffer conditions have also been reported. The base triplets predicted to occur with these triplexes have been observed in yeast transfer RNA ${ }^{\text {? }}$. Therefore our error does not alter our interpretation that the $\mathrm{T} 7$ transcript stabilizes an intramolecular DNA triplex.

Department of Microbiology,

University of Alabama at

Birmingham,

Birmingham, Alabama 35294, USA

\section{Boehringer Ingelheim}

Pharmaceuticals, Inc.,

90 East Ridge, PO Box 368.

Ridgefield, Connecticut 06877, USA

1. Reaban, M. E. \& Griffin, J. A. Nature 348, 342-344 (1990). 2. Collier, D. A., Griffin, J. A. \& Wells, R. D. J. biol. Chem. 263.
$7397-7405$ (1988).

3. Kohwi, Y. \& Kohwi. Shigematsu, T. Proc. natn. Acad. SCl. U.S.A. 85, 3781-3785 (1988)

4. Marck, T.. Thiele, D., Schneider, C. \& Guschibauer, W. Nucleic Acids Res. 5, 1979-1996 (1978).

5. Broitman. S. L., Im, D. D. \& Fresco, J. R. Proc. natn. Acad. Sct U.S.A. 84, 5120-5124 (1987)

U.S.A. 84, 5120-5124 (1987).
6. Cooney, M., Czernuszewicz, G., Postel, E. H., Flint, S. J. \& Hogan, M. E. Science 241, 456-459 (1988).

7. Cantor. C. R. \& RSchimme!, P. R. Biophysical Chemistry, Part 1: The Conformation of Biological Macromolecules (Freeman, San Francisco, 1980).

\section{Whales and the military}

SIR - Several live mass strandings of Goosebeaked whales (Ziphius cavirostris) have recently been reported ${ }^{\prime}$ on the coasts of Fuerteventura, Canary Islands. In February 1985,12 were stranded in the southern coast accompanied by a Gervais' beaked whale (Mesoplodon europaeus); in June 1986, four more were stranded alive on the northern coast, again with a single $M$. europaeus; in November 1988, three Ziphius and a single northern bottle-nosed whale (Hyperoodon ampullatus) were stranded on the southeast side (on the same date two pygmy sperm whales (Kogia breviceps) were stranded on है the neighbouring island of $\frac{3}{z}$ Lanzarote). Military manoeuvres were observed at sea close to the stranding sites in February 1985 and November 1988 (ref. 1). fitherto unre- open bars, other species; asterisks, live strandings; black ported mixed-species live arrowheads, military activity.

mass stranding occurred on Fuerteventura in October 1989; three M. europaeus came ashore with two $M$. densirostris (de Blainville's dense-beaked whale) and many Ziphius. In total, about 24 animals are estimated to have stranded by M. Pizarro, R. Vonk and V. Martin. Again, the stranding occurred when naval vessels were clearly visible out to sea. Local people have only been aware of such military manoeuvres three times since 1985; on each occasion mass live strandings have occurred. No pathological examinations were conducted on any of the stranded animals but there were no apparent abnormalities or wounds. All the stranded animals soon died.

Strandings of $M$. europaeus on the east side of the Atlantic are very rare. Before the strandings in the Canaries only two others had been reported ${ }^{2}$. There are also only a few reports of multiple deaths of Ziphius outside the Canaries'; first, off Venezuela, when four decomposed bodies washed ashore on an island (the recorder considered that an underwater explosion, related to naval manoeuvres, might be responsible; second, when the bodies of three Ziphius and a striped dolphin (Stenella coeruleoalba) came ashore on the coast of Corsica with bul-

let holes in them; and third, a mass stranding, about which no further details are known, that occurred on the east coast of the United States. Two further small strandings are also known from the Galapagos and Puerto Rico.

Details of the general pattern of strandings in the Canaries from 1981 to 1987 have been noted by Vonk and Martin, and are presented with the mass strandings of 1988 and 1989 in the figure. The island of Fuerteventura is the closest of the Canary Islands to the African mainland. It is also the main island from which local people fish (off the east side) for squid. The sea between Africa and the island may, therefore, be an important feeding ground for toothed whales. (Mesoplodon stomachs have been found to contain hundreds of squid beaks.)

Reports of military interactions with cetaceans are rare, although sperm whales in the southeast Caribbean became atypically silent and then scattered when exposed to intense underwater, local, military sonar signalling, apparently from submarines ${ }^{3}$.

Naval manoeuvres off Fuerteventura may have stimulated an invasion of the island by ships coming towards the east coast through the whales' feeding grounds. This could have driven the whales shorewards and caused them to strand. Very little is known about the biology of Ziphius, so the reason for the unusual strandings can only be the subject of speculation.

School of Biological Sciences,

M. P. SIMMONDS

Queen Mary and Westfield College,

University of London,

Mile End Road, London E1 4NS, UK

Department of Biology,

L. F. LOPEZ-JURADO

Veterinary Faculty,

University of Las Palmas,

Francisco Inglott Artiles 12,

35016 Las Palmas de Gran Canaria, Spain

1. Vonk, R. and Martin V. 1989. Proc. 3rd Ann. Conf. E.C.S. 7377 (1989).

2. Mead, J. G. Handbook of Marine Mammals (eds Ridgeway, S. H. \& Harrison, R. J.) (Academic, London 1989).

3. Watkins, W. A., Moore, K. E. \& Tyack, P. Cetology 49; 1-15 (1985). 